\title{
Comments on "Detection and identification of enteroviruses circulating in children with acute gastroenteritis in Pará State, Northern Brazil (2010-2011)"
}

\author{
Adriana Luchs ${ }^{*}$ (1)
}

\begin{abstract}
Investigation of human enterovirus (EV) in diarrheic fecal specimens is valuable to address EV diversity circulating worldwide. However, the detection of EV strains exclusively in fecal specimens must be interpreted cautiously. EV are well known causative agents associated with a spectrum of human diseases, but not acute gastroenteritis. EV isolation in stool samples could not necessarily be associated with diarrheic symptoms, as most EV infections appear to be asymptomatic, and healthy children could excrete EV in their stool. The diagnostic of EV is only confirmed when the neutralization test presents a significant increase in antibody titers (three times or more) in the paired serum samples (acute-phase and convalescent-phase) against the same EV serotype isolated in feces. In addition, patients suffering from acute gastroenteritis, even during an EV investigation, must be screened in parallel for gastroenteric viruses (i.e. norovirus and rotavirus) in order to clarify if the symptoms could be linked to other viral agent detected in their fecal samples. Surveillance of EV diversity among distinct patient groups, including diarrheic individuals, must be taken into consideration and can considerably increase the power of non-polio EV surveillance system in Brazil. More welldesigned studies are necessary to further elucidate the role of EV in acute gastroenteritis.
\end{abstract}

Keywords: Enterovirus, Acute gastroenteritis, Brazil

\section{Background}

Dr. Adriana Luchs is a researcher at the Enteric Virus Laboratory, Adolfo Lutz Institute, São Paulo, Brazil. Her research interests are in enteric viral pathogens.

I read with interest Machado et al. [1] investigation of human enterovirus (EV) associated to acute gastroenteritis in children from the state of Pará, Northern Brazil. This study would be valuable to formulate future plans to screen diarrheic fecal specimens in order to address EV

This article is Comments on to https://doi.org/10.1186/s12985-020-01431-w and Rebuttal to VIRJ-D-21-00176R1.

*Correspondence: driluchs@gmail.com

Enteric Disease Laboratory, Adolfo Lutz Institute, Virology CenterAv. Dr Arnaldo, n 355, São Paulo, SP 01246-902, Brazil diversity circulating in the country as well as worldwide. Nevertheless, I would like to share particular apprehensions and clarify some topics aiming to contribute to the knowledge of EV epidemiology.

The family Picornaviridae has undergone a significant expansion in recent years, due principally to the identification of previously unknown picornaviruses by nextgeneration sequencing of clinical and environmental samples [2]. In fact, these new members of Picornaviridae (i.e. Cosavirus and Parechovirus) have been detected in human fecal specimens, and studies have suggested their association with gastroenteritis infection [3, 4]. Nevertheless, the pathogenicity of new Picornaviridae members in humans remains unknown. On the other hand, EVs (Enterovirus genus, Picornaviridae family) are original author(s) and the source, provide a link to the Creative Commons licence, and indicate if changes were made. The images or other third party material in this article are included in the article's Creative Commons licence, unless indicated otherwise in a credit line to the material. If material is not included in the article's Creative Commons licence and your intended use is not permitted by statutory regulation or exceeds the permitted use, you will need to obtain permission directly from the copyright holder. To view a copy of this licence, visit http://creativecommons.org/licenses/by/4.0/. The Creative Commons Public Domain Dedication waiver (http://creativeco mmons.org/publicdomain/zero/1.0/) applies to the data made available in this article, unless otherwise stated in a credit line to the data. 
well known causative agents associated with a spectrum of human diseases, including acute febrile illness, handfoot-and-mouth disease, acute flaccid paralysis, aseptic meningitis, encephalitis, myocarditis, acute respiratory syndrome and neonatal sepsis, but not acute gastroenteritis [5, 6]. Indeed, none of the studies cited [7-9] by Machado et al. [1] stated the association of EV with acute diarrhea, including those one from Brazil $[10,11]$.

Employing diarrheal stools to describe and investigate EV strain diversity is definitely valid, however the authors cannot declare that EV are the causing pathogen, especially without clinical/epidemiological evaluation of the patients. Attempts to associate EV as causative agent of acute gastroenteritis are not rare [12], however the detection of EV in stool could not necessarily be associated with diarrheic symptoms, as most EV infections appear to be asymptomatic [13], and over $10 \%$ of healthy children excrete EV in their stool [14]. In addition, EVs colonize the throat and gut for weeks to months and can exhibit a lingering shedding in feces after previous infections [15]. Therefore, detection of EV exclusively in these sites must be interpreted cautiously [16]. In case of suspected EV infection, multiple samples should be collected from different sites, and the samples collection are performed following the clinical symptoms [16]. Fecal specimens alone are not the suitable for EV diagnosis. Stool samples must be accompanied by paired blood samples (acute-phase and convalescent-phase). The diagnostic of EV is only confirmed when serological tests (neutralization test) present a significant increase in antibody titers (three times or more) in the paired serum samples against the same EV serotype isolated in feces [16, 17].

At least, it is important to mention that the EV strains detected in Machado et al. [1] study were identified in fecal specimens from children suffering from acute gastroenteritis. The 175 stool samples very likely were screened for gastroenteric viruses (i.e. norovirus and rotavirus) following the algorithm of clinical symptoms at the Pediatric Clinic of Pará. The authors failed to present these data in the manuscript. As EV are classically not known to be associated with acute diarrhea $[5,6]$, the gastroenteritis symptoms observed in the patients could be linked to one (or more) of the gastroenteric viruses eventually detected in their fecal samples.

\section{Conclusion}

Identifying the circulating EV strains in Brazilian inhabitants is vital to elucidate the enteroviral biodiversity in the country and improve our understanding of their potential health burden, especially considering the capacity of EV to remain in silent circulation in populations [11]. Surveillance of EV diversity among distinct patient groups, including diarrheic individuals, must be taken into consideration and can considerably increase the power of non-polio EV surveillance system in Brazil. More welldesigned studies are necessary to further elucidate the role of EV in acute gastroenteritis.

\section{Abbreviation \\ EV: Enterovirus.}

Acknowledgements

Not applicable.

Authors' contributions

$\mathrm{AL}$ conceived the ideia, prepared the original draft, read and approved the final manuscript.

\section{Funding}

None.

Availability of data and material

Not applicable.

\section{Declarations}

Ethics approval and consent to participate

Not applicable.

\section{Consent to publication}

Not applicable.

\section{Competing interests}

The author declare that there is no conflicts of interest.

Received: 14 January 2021 Accepted: 10 June 2021

Published online: 30 June 2021

\section{References}

1. Machado RS, de Sousa Jr IP, Monteiro JC, et al. Detection and identification of enteroviruses circulating in children with acute gastroenteritis in Pará State, Northern Brazil (2010-2011). Virol J. 2020;17(1):156.

2. da Costa AC, Luchs A, Milagres FAP, et al. Near full length genome of a recombinant (E/D) cosavirus strain from a rural area in the central region of Brazil. Sci Rep. 2018:8(1):12304.

3. Holtz LR, Finkbeiner SR, Kirkwood CD, Wang D. Identification of a novel picornavirus related to cosaviruses in a child with acute diarrhea. Virol J. 2008:5:159.

4. Kapoor A, Victoria J, Simmonds P, et al. A highly prevalent and genetically diversified Picornaviridae genus in South Asian children. Proc Natl Acad Sci USA. 2008;105(51):20482-7.

5. Khetsuriani N, Lamonte-Fowlkes A, Oberst S, et al. Enterovirus surveillance-United States, 1970-2005. MMWR Surveill Summ. 2006;55(8):1-20.

6. Khetsuriani N, Kutateladze T, Zangaladze E, et al. High degree of genetic diversity of non-polio enteroviruses identified in Georgia by environmental and clinical surveillance, 2002-2005. J Med Microbiol. 2010;59(Pt 11):1340-7

7. Das JK, Salam RA, Bhutta ZA. Global burden of childhood diarrhea and interventions. Curr Opin Infect Dis. 2014;27(5):451-8.

8. Goodgame RW. Viral causes of diarrhea. Gastroenterol Clin North Am. 2001:30(3):779-95.

9. Tapparel C, Siegrist F, Petty TJ, Kaiser L. Picornavirus and enterovirus diversity with associated human diseases. Infect Genet Evol. 2013;14:282-93.

10. Ribeiro GO, Luchs A, Milagres FAP, et al. Detection and characterization of enterovirus B73 from a child in Brazil. Viruses. 2018;11(1):16.

11. Luchs A, Leal E, Tardy K, et al. The rare enterovirus C99 and echovirus 29 strains in Brazil: potential risks associated to silent circulation. Mem Inst Oswaldo Cruz. 2019;114:e190160. 
12. Rao CD. Enteroviruses in gastrointestinal diseases. Rev Med Virol. 2020;31:e2148.

13. Zhang Y, Cao J, Zhang S, et al. Genetic changes found in a distinct clade of Enterovirus D68 associated with paralysis during the 2014 outbreak. Virus Evol. 2016;2(1):vew015.

14. Witsø $E$, Palacios $G$, Cinek $O$, et al. High prevalence of human enterovirus a infections in natural circulation of human enteroviruses. J Clin Microbiol. 2006;44(11):4095-100.

15. Duan X, Chen Z, Li X, et al. Virus shedding in patients with hand, foot and mouth disease induced by EV71, CA16 or CA6: systematic review and meta-analysis. Pediatr Infect Dis J. 2020. Epub ahead of print.
16. Harvala H, Broberg E, Benschop K, et al. Recommendations for enterovirus diagnostics and characterisation within and beyond Europe. J Clin Virol. 2018;101:11-7.

17. de Moraes JC, Toscano CM, de Barros EN, et al. Etiologies of rash and fever illnesses in Campinas, Brazil. J Infect Dis. 2011;204(Suppl 2):S627-36.

\section{Publisher's Note}

Springer Nature remains neutral with regard to jurisdictional claims in published maps and institutional affiliations.
Ready to submit your research? Choose BMC and benefit from:

- fast, convenient online submission

- thorough peer review by experienced researchers in your field

- rapid publication on acceptance

- support for research data, including large and complex data types

- gold Open Access which fosters wider collaboration and increased citations

- maximum visibility for your research: over $100 \mathrm{M}$ website views per year

At BMC, research is always in progress.

Learn more biomedcentral.com/submissions 